\title{
Investigation of University Students' Attitudes to Play Educational Games and Games Consisting of Physical Activity
}

\author{
Osman Gumusgul ${ }^{1, *}$ \\ ${ }^{1}$ School of Physical Education and Sports, Kutahya Dumlupinar University, Turkey \\ *Correspondence: School of Physical Education and Sports, Kutahya Dumlupinar University, Turkey. Tel: \\ 90-274-227-0458. E-mail: osmangumusgul@gmail.com
}

Received: February 12, 2019

Accepted: March 17, 2019 Online Published: March 21, 2019

doi:10.5430/wje.v9n2p31

URL: https://doi.org/10.5430/wje.v9n2p31

\begin{abstract}
The aim of this study was to investigate attitudes of university students to play educational games and games consisting of physical activity. Totally, 514 students (187 male, 327 female) were taken part in this research. Data was gathered through Attitudes to Play Games Consist of Physical Activity Scale (Playfulness Scale) which was developed by Hazar (2014). The scale has 23 items. In evaluation part for questionnaires answered by participants, Kolmogorov Smirnov normality test, Mann Whitney-U and Kruskal Wallis tests were applied. According to the results, it was statistically determined that there were significant differences between playing games consist of physical activity attitudes and gender, practicing any sport licenced and age $(\mathrm{p}<0,05)$; but there were not significant differences on analyses done for academic success $(\mathrm{p}>0,05)$.
\end{abstract}

Keywords: educational games, recreational games, physical activity, university students

\section{Introduction}

Game has been an important event in every person's life. For an adult, game can mean relaxing, free time activity and so on. For a child it can express meanings to recognize and understand the world in which he lives, and the people around him. For this reason, play should not be regarded as a leisure activity only but also a serious occupation that takes up a large part of the child's time (Oktay, 1987).

The game is an important factor in supporting child development. It contributes to physical, spiritual, emotional and social development. The child establishes a relationship between his own world and the environment through play. The children learn without realizing in the game environment (Paino, 2001; Korkmaz, 2018).

Based on the studies on games, the game has a key role in every aspect of the child's life. The game allows the development of the child. It is clear that this concept, which is so important for the child, will be effective in playing games by playing games or developing games (Ersoy, 1999).

Students gain experience and think about playing games. It is an active learning and natural learning method for students, also having experience of learning by doing and experiencing in the game. They listen, sense, smell and taste. They can use all sense organs. Thus learning takes place in a natural state and becomes permanent (Ceker, 2017).

Game theories are divided into three as classical, recent and contemporary. Classical theory argues that the game is a mean of reducing the stress of individuals and renewing the individual. The basis of the game is to burn the excess energy and the skills in the games are innate. None of the classical theories are based on evidence, but is still valid in this day and age (Karakucuk, 2016).

The recent-era theory argues that through play, the child can solve his problems. The game gives the child information that no creature can teach. The game frees aggressive energy stored in individuals. If the individual is very bored in his work, he should be able to discard this bad energy in his free time (Feshbach, 1956; Torkildsen, 1992; Kraus, 2001).

Modern thoughts have emerged in contemporary theories. According to this theory; game may not always be fun and enjoyable, sometimes it can be frustrating or boring. Individual characteristics shape the attitudes of the game. The 
environment of the individual, anatomical structure etc. affects the behavior of the game. The game should have a certain level; if it is too simple it can cause boredom, and if it is too difficult it can cause anxiety (Huizinga, 1960; Kraus, 2001).

Educational game is the teaching method which supports the development of knowledge in a comfortable environment, the formation and consolidation of the information learned, and the development of the skills in a fun way (Guler, 2011).

The play that affects all areas of development is the indispensable learning tool of learner. Students are socialized in the game, which helps them to get acquainted with the environment. The game not only affects their development areas; but also to teachers, family, etc. It is an activity that provides people with an environment of recognizing and understanding them (Kocyigit, et al., 2007).

According to Kreuzer, those who manage educational games need to be self-developed in a pedagogical, emotional, communicative and educational manner. Teachers must assume the role of organizing the game during the game. For teacher, in order to motivate the students to play and activate them for the game, they must not have a negative idea against the game. Teacher should not completely isolate themselves from the event during the play activity (Baris, 2000).

Educational games have many contributions to education. For example, it allows students to participate actively in the lesson. Provides the information learned in a fun environment to be repeated and permanent. Improves mental, physical and affective characteristics of the students. Students use old information together with new ones. This ensures that students link knowledges and thanks to this learning becomes effective (Sel, 1987).

With technologic developments, over the years, the use of computer games in education and consequently, students' interest in educational computer games has gradually increased (Korkusuz, 2012). Today, with the growth of the gaming industry, the expansion of broadband internet and the advancement of computer technology, educational games have also been developed. Now, educational games allow many students to have fun and learn together as part of a social structure (Turvey, 2006).

Studies have shown that learning with games is more effective in increasing academic achievement than traditional teaching method. Teaching method is important in terms of providing fun while learning for children and increasing academic achievement. According to Adler (1997) and Stanley (2009), learning with games is one of the most effective methods. Learning with games also helps children learn basic scientific concepts (Sahin, 2001). The method of educational games make the subjects and lessons interesting and it increases attitudes of the students towards lesson and school positively (Onen et al., 2012).

\section{Method}

\subsection{Design of the Study}

The study has been carried out on the basis of quantitative research design. The study is suitable for the relational scanning model that is one of the general scanning models for defining to determine the relationship between research variables, which is the general scanning model is made to scan on the universe of all or a sample taken from it to reach a general judgment about universe at a stage consisting of a plurality of elements (Karasar, 2012; Isik, 2018).

\subsection{Sample of the Study}

514 students selected randomly studying at School of Physical Education and Sports, Faculty of Education and Faculty of Economics and Administrative Sciences took part in this research. Demographic features of participants are pointed out at Table 1 . 
Table 1. Demographic Features of Participants

\begin{tabular}{llll}
\hline Factor & Variable & $\mathbf{N}$ & $\mathbf{\%}$ \\
\hline \multirow{2}{*}{ Gender } & Male & 187 & 36,4 \\
& Female & 327 & 63,6 \\
Age & 20 years old and younger & 124 & 24,1 \\
& $21-23$ years old & 285 & 55,4 \\
& 24-26 years old & 63 & 12,3 \\
& 27 years old and older & 42 & 8,2 \\
Department & Physical Education and Sports & 140 & 27,2 \\
& Faculty of Education & 101 & 19,6 \\
Educational Game & Faculty of Eco. and Ad. Sci. & 273 & 53,1 \\
& Yes & 187 & 36,4 \\
Activity on Free Time & No & 327 & 63,6 \\
& Physical activities & 111 & 21,6 \\
& Social Activies & 315 & 61,3 \\
& Cultural /Art activity & 88 & 17,1 \\
Academic Success(on 4,00) & 2,00 and less & 84 & 16,3 \\
& $2,01-2,50$ & 90 & 37 \\
& $2,51-3,00$ & 167 & 32,5 \\
& $3,01-4-00$ & 73 & 14,2 \\
\hline
\end{tabular}

\subsection{Data Collection Tool}

Developed to measure attitudes of university students to play games which consist of physical activity, Playfulness Scale (Hazar, 2014) was applied as data collection tool in this study. Playfulness scale developed by Hazar (2014) consists of 23 items and 2 sub dimensions being "Cognitive dimension of the game "(11 items) and "Behavioural dimension of the game" (12 items). The answer codes to be given for each item differ between 1.00 and 5.00. Grading items in the scale are as follows: Strongly agree (5), agree (4), neutral (3), disagree (2), strongly disagree (1).

\subsection{Analysis of the Data}

The data gathered from the participants was evaluated with the statistics package program SPSS 22.0. In evaluation part for questionnaires answered by participants, Kolmogorov Smirnov normality test, Mann Whitney-U and Kruskal Wallis tests were applied. According to the results, it was statistically determined that there were significant differences between playing games consist of physical activity attitudes and gender, practicing any sport licenced and age $(\mathrm{p}<0,05)$; but there were not significant differences on analyses done for academic success $(\mathrm{p}>0,05)$.

\section{Results}

Table 2. Playing Games Consist of Physical Activity Scores According to Gender

\begin{tabular}{|c|c|c|c|c|c|c|}
\hline & Gender & $\mathbf{n}$ & Mean Rank & $\mathbf{U}$ & $\mathbf{Z}$ & $\mathbf{p}$ \\
\hline $\begin{array}{l}\text { Cognitive dimension of the } \\
\text { game }\end{array}$ & $\begin{array}{l}\text { Male } \\
\text { Female }\end{array}$ & $\begin{array}{l}187 \\
327\end{array}$ & $\begin{array}{l}237,89 \\
267,96\end{array}$ & 26907,50 & $-2,214$ & $0,027 *$ \\
\hline $\begin{array}{l}\text { Behavioural dimension of the } \\
\text { game }\end{array}$ & $\begin{array}{l}\text { Male } \\
\text { Female }\end{array}$ & $\begin{array}{l}187 \\
327\end{array}$ & $\begin{array}{l}281,03 \\
244,04\end{array}$ & 26173,50 & $-2,718$ & $0,007 *$ \\
\hline
\end{tabular}


As a result of the Mann-Whitney-U analysis, it was found that there was statistically significant difference in 0,05 significance level between the sub-dimensions of female and male participants $(\mathrm{p}<0,05)$. As shown in Table 2 , female participants had statistically higher scores in Cognitive sub dimension of game $(z=-2,214 ; p<0,05)$ compared to the male participants, whereas the male participants had statistically higher scores in Behavioural sub dimension of game $(z=-2,718 ; p<0,05)$. In other words, female participants had higher mean score in the Cognitive sub dimension of game than male participants, whereas male participants had higher mean score in Behavioural sub dimension of game than female participants.

Table 3. Playing Games Consist of Physical Activity Scores According to Licenced Sports

\begin{tabular}{lllllll}
\hline & $\begin{array}{l}\text { Licensed } \\
\text { Sports }\end{array}$ & $\mathbf{n}$ & Mean Rank & $\mathbf{U}$ & $\mathbf{Z}$ & $\mathbf{p}$ \\
\hline $\begin{array}{l}\text { Cognitive sub dimension of the } \\
\text { Yes }\end{array}$ & 129 & 281,62 & \multirow{2}{*}{20901,00} & $-2,296$ & $0,022^{*}$ \\
No & 385 & 246,93 & & & \\
Behavioural sub dimension of & Yes & 129 & 275,83 & 21757,00 & $-1,737$ & 0,082 \\
the game & No & 385 & 249,51 & & & \\
\hline
\end{tabular}
$* \mathrm{p}<0,05$

The results of Mann-Whitney U test on the sub-dimensions of Playfulness Scale show that the participants differ significantly in terms of cognitive sub dimension of the game according to practicing any sports as licensed $(\mathrm{p}<0,05)$. This finding indicates that participants practice any sports with license has statistically significant higher scores in cognitive sub dimension of the game $(\mathrm{z}=-2,296 ; \mathrm{p}<0,05)$. Otherwise there is not significant difference between behavioural sub dimensions of the game and participants practicing any sports as licensed $(z=-1,737 ; p>0,05)$.

Table 4. Playing Games Consist of Physical Activity Scores According to Age

\begin{tabular}{|c|c|c|c|c|c|c|}
\hline & Age & $\mathbf{N}$ & Mean Rank & df & $\mathbf{X}^{2}$ & $\mathbf{P}$ \\
\hline \multirow{4}{*}{$\begin{array}{l}\text { Cognitive } \\
\text { dimension of } \\
\text { game }\end{array}$} & 20 years old and younger & 124 & 251,21 & \multirow{4}{*}{3} & \multirow{4}{*}{7,879} & \multirow{4}{*}{$.049^{*}$} \\
\hline & $21-23$ years old & 285 & 269,68 & & & \\
\hline & $24-26$ years old & 63 & 212,87 & & & \\
\hline & 27 years old and older & 42 & 254,56 & & & \\
\hline \multirow{4}{*}{$\begin{array}{l}\text { Behavioural } \\
\text { dimension of } \\
\text { game }\end{array}$} & 20 years old and younger & 124 & 257,59 & \multirow{4}{*}{3} & \multirow{4}{*}{1,166} & \multirow{4}{*}{.761} \\
\hline & 21-23 years old & 285 & 255,90 & & & \\
\hline & 24-26 years old & 63 & 273,83 & & & \\
\hline & 27 years old and older & 42 & 243,56 & & & \\
\hline
\end{tabular}

$* \mathrm{p}<0,05$

Table 4 shows the Kruskal-Wallis test results according to age of the participants in the study. According to the results of the analysis, there was no significant difference between behavioural sub dimension according to participants' age $(\mathrm{X} 2(3)=1,166 ; \mathrm{p}>0.05)$; but significant differences were found in cognitive sub-dimension of the game $(\mathrm{X} 2(3)=7,879 ; \mathrm{p}<0.05)$.

Table 5. Playing Games Consist of Physical Activity Scores According to Academic Success

\begin{tabular}{lllllll}
\hline & Age & N & Mean Rank & df & $\mathbf{X}^{\mathbf{2}}$ & P \\
\hline \multirow{3}{*}{$\begin{array}{l}\text { Cognitive sub dimension } \\
\text { of the game }\end{array}$} & 2,00 and less & 84 & 233,12 & & & \\
& $2,01-2,50$ & 190 & 245,86 & 3 & 6,889 & .076 \\
& $2,51-3,00$ & 167 & 270,35 & & & \\
\multirow{2}{*}{$\begin{array}{l}\text { Behavioural } \\
\text { dimension of the game }\end{array}$} & $3,01-4-00$ & 73 & 283,29 & & & \\
& 2,00 and less & 84 & 245,10 & & & \\
$* \mathbf{p}<0,05$ & $2,01-2,50$ & 190 & 263,00 & 3 & 1,453 & .693 \\
& $2,51-3,00$ & 167 & 262,42 & & & \\
\hline & $3,01-4-00$ & 73 & 246,21 & & &
\end{tabular}


According to Kruskal-Wallis test results of participants academic success, there was no significant difference between Playing games consist of physical activity and participants' academic success. Even though participants who had better academic scores also had higher scores in cognitive sub dimension of the game, it was not significantly different according to the analyses $(\mathrm{X} 2(3)=6,889 ; \mathrm{p}>0.05)$. Also there was not significant difference between behavioural sub dimensions of the game and academic success $(X 2(3)=1,453 ; p>0.05)$.

\section{Discussion}

In this study, it was aimed to investigate playing games consist of physical activity attitudes of participants studying at School of Physical Education and Sports, Faculty of Education and Faculty of Economics and Administrative Sciences.

According to the results, it was statistically determined that there were significant differences between playing games consist of physical activity attitudes and gender, practicing any sport licenced and age $(p<0,05)$; but there were not significant differences on analyses done for academic success $(\mathrm{p}>0,05)$.

Mann-Whitney-U analysis applied to data showed that female participants had statistically higher scores in Cognitive sub dimension of game than male participants; whereas male participants had statistically higher scores in behavioural sub dimension of game. Although it can be seen that female participants desire to play more than male participants, it is observed that male participants have more action than female and turn this situation into practise. This situation can be related to the social structure of society that female participants can be shyer to move than male participants.

The results of Mann-Whitney U test pointed out that the participants practice any sports with license has statistically significant higher scores in cognitive sub dimension of the game even if there is not significant difference between behavioural sub dimensions of the game also the participants practicing any sports as licensed has higher scores. The reason can be thought that individuals who are licensed in any sports are more accustomed to game format due to their practising habits and experiences and they can be more open to education by educational games.

Kruskal-Wallis test was applied to determine if there was significant difference between attitudes of university students to play games which consist of physical activity and their age. According to the results of the analysis, there was significant differences between cognitive sub-dimension of the game and ages of participants. The results shows that younger participants are more inclined to play games which consist of physical activity.

According to Kruskal-Wallis test, even though there was not statistically significant difference, participants who had better academic scores also had higher scores in cognitive sub dimension of the game.

One Way Anova was applied applied to determine whether there was statistically meaningful difference between participants' smartphone addiction scores and age variable. Tukey test reveals that 20 years old and younger participants cause statistically significant difference. Applications for smartphones aim mostly younger users and this can cause younger university students using smartphones have higher scores than older students. On the contrary, Yildirim et al. (2015) and Adnan \& Gezgin (2016) found no significant difference between nomophobia and age variable on their studies.

University students practicing recreational sports have fewer score than the ones not practicing any recreational sports. It can give a clue that smartphones are constraints for physical activities and this may be a reason for a sedentary lifestyle and unhealthy individuals. On the other hand, Yalcin et al. (2017) has found that there is significant relation between participating free time activities and smartphone addiction with consideration of students tend to use smartphones as an effective means of communication in achieving the results they desire and to show these results to their friends and increase their self-esteem with motivational factors such as appreciation, a and fame in social platforms and reaching free time and satisfaction levels. The other result of the study points that whichever recreational activity individuals participate, makes statistically no difference and all scores are few to be smartphone addicted.

T-test was applied to examine whether there was statistically meaningful difference between participants' smartphone addiction scores and academic success and statistically no significant difference has been determined. There are different studies in literature examining effect of using smartphones and on students' academic performance and academic success (Hong et al., 2012; Krajewska Kulak et al., 2012; Kaur \& Sharma, 2015; Pellowe et al., 2015; Gupta et al., 2016; Akillı \& Gezgin, 2016). All these studies state that students who are affected by the nomophobia are experiencing sleeping problems and are skeptical about motivating even their daily work aside from academic studies. This situation also affects the educational life of the students. It is thought these results may lead to a 
decrease in the cognitive performance of learners and also in the yield and quality of the learners, and difficulty in remembering.

\section{Conclusion}

With these results, it is seen very possible to discuss about the importance of the game in education. The game contributes to physical, spiritual, emotional and social development. Learning performance of students has been improved with the tasks they have in the game. Adler (2007) and Stanley (2009) also concluded that learning with games is one of the most effective methods in education. Moreover, at Bayirtepe and Tuzun's study (2007) it was concluded that the educational play method make lessons more interesting.

\section{References}

Adler, A. (1997). Insani tanıma sanati (6th ed.). Trans. K. Sipal. Istanbul: Say Yayincilik.

Barış, B. (2000). Spiele im Deutschunterricht, Yüksek Lisans Tezi, İstanbul Üniversitesi, Sosyal Bilimler Enstitüsü, İstanbul.

Bayirtepe, E., \& Tuzun, H. (2007). Oyun-Tabanlı öğrenme ortamlarının öğrencilerin bilgisayar dersindeki başarıları ve öz-yeterlik algıları üzerine etkileri. Hacettepe Üniversitesi Eğitim Fakültesi Dergisi, 33, 41-54.

Ceker, E. (2017). Eğitsel Şarkı ve Oyunlarla İslenen Fen Bilimleri Dersinin Akademik Başarl ve Kalıcllı Üzerine Etkisi. Yüksek Lisans Tezi, Bayburt Üniversitesi, Sosyal Bilimler Enstitüsü, Bayburt.

Ersoy, O. (1999). 0-6 Yaş Çocukları için oyuncak seçimi. Yaşadikca Eğitim Dergisi, 64, 5-9.

Feshbach, S. (1956). The catharsis hypothesis and some consequences of interaction with aggressive and neutral play. Journal of Personality, 24, 449-462. https://doi.org/10.1111/j.1467-6494.1956.tb01281.x

Guler, T. (2011). 6. Sinlf Fen ve Teknoloji Dersindeki 'Hücre ve Organelleri Konusunun Eğitsel Oyun Yöntemiyle Ögrretilmesinin Öğrencilerin Akademik Başarısına Etkisi, Yüksek Lisans Tezi, Atatürk Üniversitesi, eğitim Bilimleri Enstitüsü, Erzurum.

Huizinga, J. (1960). Homo Ludens: A Study of the Play Element in Culture. Beacon Pres, Boston Mass.

Isik, U., \& Cengiz, R. (2018). The Relationship between humor styles and five factor personality traits of physical education and sports students. Universal Journal of Educational Research, 6(8), 1811-1818. https://doi.org/10.13189/ujer.2018.060826

Karakucuk, S. (2016). Rekreasyon Bilimi. Gazi Kitabevi, Ankara.

Karasar N. (2012). Bilimsel Araştırma Yontemi (21st ed.). Ankara: Nobel Yayın Dagitim.

Koçyiğit, S., Tuğluk, M. N., \& Kök, M. (2007). Çocuğun Gelişim Sürecinde Eğitsel Bir Etkinlik Olarak Oyun. Kazim Karabekir Egitim Fakultesi Dergisi, 16, 324-342.

Korkmaz, S. (2018). Eğitsel Oyun Geliş̧tirerek Desteklene Fen Bilimleri Öğretiminin Öğrenci Tutum ve Başarısına Etkisi. Yüksek Lisans Tezi, Bartın Üniversitesi, Eğitim Bilimleri Enstitüsü, Bartın.

Korkusuz, M. E. (2012). Elektrogame Eğitsel Oyununun Tasarlanıp Geliştirilerek Basit Elektrik Devreleri Konusunda Bilişssel ve Duyuşsal Değişkenlere Etkisinin İncelenmesi. Doktora Tezi, Balıkesir Üniversitesi, Fen Bilimleri Enstitüsü, Balıkesir.

Kraus, R. (2001). Recreation and Leisure. Burlington: Jones and Bartlett Publishers.

Kreuzer, K. J. (1983). Handbuch der Spielpadagogik. das Spiel im Frühpadagogischen und Schulischen Bereich. Düsseldorf: Schwann Verlag.

Oktay, A. (1987). Okul Öncesi Dönemde Çocuğun Temel Uğraşı Oyun. Pembe Bagcik Dergisi, 4, 8-10.

Onen, F., Demir, S., \& Şahin, F. (2012). Fen Oğretmen Adaylarının Oyunlara Iliskin Görüsleri ve Hazırladikları Oyunlarin Degerlendirilmesi. Ahi Evran Üniversitesi Kirsehir Egitim Fakultesi Dergisi (Kefad), 13(3), 299-318.

Paino, P. (2001). Games students play. Science Teacher, 68(4), 28-30.

Sahin, F. (2001). Illkögretim Fen Ögretiminde Oyunların Yeri ve Önemi. Yeni Binyllın Basinda Türkiye'de Fen Bilimleri Egitimi. Sempozyumu Bildiriler Kitabı (ss. 22- 26). İstanbul: Marmara Üniversitesi.

Sel, R. (1987). Ĕgitsel Oyun. Ankara: Öğretmen Yayinlari 
Stanley, M. (2009). Çocuk ve Beceri (1st ed.). İstanbul: Ekinoks Yayincilik.

Torkildsen, G. (1992). Leisure and Recreation Management. London: Spon Pres.

Turvey, K. (2006). Towards deeper learning through creativity within online communities in primary education. Computers \& Education, 46(3), 309-321. https://doi.org/10.1016/j.compedu.2005.11.004 